\title{
The Impact of Managers' Related Variables and Department Features on Budget Characteristics: The Case of Private Jordanian Universities
}

\author{
Dr. Mahmoud Nasser, Dr. Osama Mah'd, Dr,Khalil Nimer \& Dr.Saleh Al-okdeh
}

Received: May 24, 2011

Accepted: July 5, 2011

doi:10.5539/ibr.v4n4p199

\begin{abstract}
This study investigates the influence of manager and department variables on budget characteristics in private Jordanian universities. This paper aims to study the relationship between the departments' heads characteristics and department features with the budget participation, information sharing, budget adequacy, goal clarity, and budget feedback in private universities in Jordan. It draws on relevant prior studies in the management accounting particularly budget issues to formulate the research questions and implementing survey method with seventy seven functional managers in five private Jordanian universities to shed light upon the perceptions of proposed budget participants. The results indicate that there is no such a relation between the department type and size with the budget characteristics, and no significant association between most of the manager related variables and budget characteristics. In contrast, the results indicate that the experience earned in the university has a significant strong relation with budget characteristics and weak relation has been found between manager budget experience and budget characteristics. The data suggest that the department factors and the manager factors except the experience earned in the university and the budget experience have no impact on budget characteristics. Hence, the budget characteristics may influence other factors such as the management style, departmental autonomy.
\end{abstract}

Keywords: Budget characteristics, Manager related factors, Department features, Private Jordanian universities

\section{Introduction}

Prior studies demonstrate that the budget is an important tool of management accounting in terms of control, coordination, and decision-making (Drury, 2008; Covaleski et al., 2003; and Mah'd, 2010). Furthermore, great attention has been given to the influence of budgetary systems in the control of organisations in terms of the size, structure, managerial autonomy, and external environment (Merchant, 1981; Ezzamel, 1990; and Bruns \& Waterhouse, 1975). By contrast, little attention appears to be directed to the question of how the budgetary process in university departments varies regarding to manager characteristics and department characteristics. Furthermore, few studies have researched budget participation, information sharing, goal clarity, budget adequacy and budget feedback in private universities in developing countries. This study tends to shed light on the relationship between the demographic variables and the budget characteristics in private Jordanian universities.

Budget characteristics in the current research are identified as budget participation, information sharing, goal clarity, budget adequacy and budget feedback. The need for participative budgeting has been clarified in the literature. Great attention in the management accounting literature focuses on the impact of the participative budgetary process on outcome variables such as job performance (Stedry, 1960; Milani, 1975; Kren, 1992; Nouri \& Parker, 1998; Fisher et al., 2006; and Parker \& Kyj 2006), job satisfaction (Brownell \& McInnes, 1986), motivation (Mia, 1989) and employee effort (Fisher et al., 2006). Others consider participation in the budget very important that it encourages managers to be motivated and involved with their department activities (See Hofstede, 1967; Kenis, 1979; Merchant, 1981; Brownell \& Hirst, 1986; and Dunk, 1993). Several prior researchers (e.g. Shields \& Shields, 1998; Parker \& Kyj, 2006) suggest that budget participation can play an essential role in establishing an accepted and well-organised budget.

Private universities in Jordan vary in the size, the structure and program diversity. Five different universities have been examined in this paper to give more generality to the research. The departments' managers in these universities are the main target of the research. The impact of department managers' position, qualification, major, general experience, experience earned in the university, budget experience, department type, department size on selected budget related factors have been examined. It is worth mentioning that all these universities are accredited by the Ministry of Higher Education (MoHE), using the ministry budget format and working according to the MoHE rules.

The current paper contributes to the growing accounting literature by examining the interaction between the features of the cost unit actors (department managers) and budget characteristics. The usefulness of organisational and contingency theory has established the relation between the contextual variables and the budget characteristics. Furthermore, these results are engaged with the prior studies as this is one of the motivations of this paper. 


\section{Literature review}

The effect of organisation context on the budget features has been extensively examined in the literature (Burns \& Waterhouse, 1975; Kenis, 1979; Merchant, 1981; Ezzamel, 1990; and Nouri \& Kyj, 2008). The influence of corporate budgeting systems on managerial behaviour and organisational performance has been studied by examining the effect of corporate context on the level of participation (Merchant, 1981). Merchant notes that managers in the larger, more diverse, decentralized companies participated more highly in budget setting. Moreover, Ezzamel finds that middle and lower-level managers are likely to be better participants in the budget in organizations characterized by large size, decentralized structure, and greater Perceived Environmental Univercity (PEU). Similarly, Bruns \& Waterhouse (1975) find that large organizations, and decentralized organisations, tend to allow greater participation in budgets. Kenis (1979) suggests that budgetary participation and goal clarity affect positively on job- related and budget related attitudes of managers. The following is brief explanation of the prior studies in budget participation, information sharing, role ambiguity, budget adequacy and budget feedback.

\subsection{Budget characteristics}

The results in prior studies have indicated that the contextual variables have a significant impact on the budget usage and budget characteristics (see Ezzamel, 1990; Kenis, 1979; Merchant, 1981; and Nouri \& Kyj, 2008). Merchant (1981) finds that larger and more diverse departments have significant effect on how department managers use their budget, even though the managers are using the same corporate budgeting system. Ezzamel (1990) finds that perceived environmental uncertainty have strong impact on budget participation, budget evaluation, required explanation of the variances, and information sharing. Figure 1 describes the five selected characteristics which have been used in the current study as dependent variables. Prior studies (e.g. Milani, 1975; Kenis, 1979; Merchant, 1981; Ezzamel, 1990; Sheilds \& Shields, 1998; Parker \& Kyj, 2006;Mah'd,2010 and Nouri \& Kyj, 2008) find these factors as important budget characteristics to facilitate budget process and to encourage participative budgeting. Those characteristics have been chosen relying on budget literature and the environment of universities in Jordan.

Budget characteristics include budget participation, information sharing, organisational commitment, role ambiguity, and job performance was measured using a survey questionnaire by (Parker \& Kyj, 2006). Early study, Stedry (1960) examine the relationship between the types of budget and individual performance. Shields and Shield (1998) review budgetary participative in 47 management studies, focus on the effects of participative budgeting. Budget participation can lead to greater understanding of the budget settings, greater trust in budget targets, and lowering the subordinates fear, apprehension and suspicion of budget targets (Lau \& lim, 2002). Nouri \& Parker (1998) theorize the statement of 'Budget leads to budget adequacy, directly and via organisational commitment leads to job performance' as a basic of theoretical model used in their paper.

\subsection{Budget participation}

Budget participation has been extensively investigated in management accounting literature using participative budgeting as an independent variable. Participative budgeting can be examined directly with dependent variables such as job performance or satisfaction or associated indirectly, mediated by an intervening variable, with dependent variables (Stedry, 1960; Sheilds \& Sheild, 1998; Nouri \& Parker, 1998; Fisher et al., 2006; and Parker \& Kyj 2006). Prior studies vary in the results examining the relationship between budget participation and managerial performance. While, some studies outline a significant positive relationship between budget participation and managerial performance (Chenhall \& Brownell, 1988; Lau \& Lim, 2002; Moll, 2003; and Parker \& Kyj, 2006), others find insignificant relation or negative association (e.g. Milani, 1975; Kenis, 1979). Nevertheless, huge number of them uses some factors as intervening variable to mediate this relationship. These variables have been used by (Nouri \& Parker, 1998) organisational commitment, (Chenhall \& Brownell, 1988) role ambiguity, (Parker \& Kyj, 2006) information sharing, (Brownell \& McInnes 1986) motivation, (Nouri \& Parker, 1998) budget adequacy, (Kren 1992; Chong \& Chong, 2002) job relevant information and other variables. However, the linkage between participative budgeting and outcome variables has extensively studied, the results are inconsistent in explaining this relation.

The arguments in favourite of budget participation are so varied and so vague in last decades (Hopwood, 1974; Parker Kyj, 2006; and Nouri \& Kyj, 2008). The influence of budget participation is perhaps the most examined budget aspects in the research literature (Lukka, 1988; Shields \& Shields, 1998; and Charpentier, 1998), although this may not apply to budget literature in developing countries.

The level of participation in setting the budget is likely to be different between managers in the universities depending on their characteristics as well as depending on the department characteristics. There might therefore be different motivation and understanding for the budget participation in between those managers who have different position, qualification, major general experience, organisational experience, and budget experience. Moreover, there could be different level of participation in budget setting depending on the context of the department in terms of the 
size and the type. In general, the current study investigates such a relationship between the manager characteristics and department factors with budget participation as one of the budget characteristics.

\subsection{Information sharing}

An important benefit of the budgeting process is sharing information between subordinates and their managers (Hopwood, 1974; Covaleski et al., 2003; and Parker \& Kyj, 2006: Thys-Clement \& Wilkin, 1998; Mah'd 2010; and Broadbent, 2007). Shield \& Shield (1998) and Parker \& Kyj (2006) support Shields and Young's (1993) argument that budget participation is used to facilitate the communication of private information from subordinates to superiors. A common assumption in the accounting literature (especially agency theory) is that subordinate managers hold private information regarding their task and know about their operational areas more than do their superiors (Merchant, 1981; Nouri \& Parker, 1998; Shields \& Shields, 1998; and Covaleski et al., 2003). The flow of information up-down has also been addressed in the literature (Kren, 1992; Parker \& Kyj, 2006) that superiors generally have private information regarding to achieve strategic budget goals which may facilitate the subordinates achievement of those goals (Gladney et al., 2009). Budget participation may enable subordinates and superiors to communicate their private information leading to better decision-making and budget (Nouri \& Parker, 1998; Shields \& Shields, 1998; Covaleski et al., 2003; and Parker \& Kyj, 2006).

\subsection{Goal clarity}

Goal clarity has been defined in the literature as the extent to which goals are clear, stated specifically and understood by the employees (Kenis, 1979). Another term appears in the literature is role ambiguity. Role ambiguity shows that an employee is uncertain about his role within the organisation. It is argued that participation in the budget setting process has potentially to clarify the role (Chenhall \& Brownell, 1988). Several empirical evidences suggest that as intervening variable between budget participation and job performance role ambiguity has a significant negative association with individual performance (Chenhall \& Brownell, 1988; Parker \& Kyj, 2006). Parker \& Kyj (2006) find not only role ambiguity has a significant negative relationship with job performance but also role ambiguity has negative relation with organisational commitment.

Chenhall \& Brownell (1988) view the role ambiguity as the extent to which clear information is lacking regarding to the expectations associated with the role, methods, and the consequence of role performance. They argue that through budget participation, subordinates gain information that make their organisational roles clear. Their find that budgetary participation help to decrease manager's role ambiguity and this decrease improves job satisfaction and performance. Parker \& Kyj (2006) suggest that both job performance and organisational commitment is affected directly and adversely by role ambiguity. Further, indirectly role ambiguity affects information sharing through organisational commitment. Previous research suggest association between role ambiguity, budget participation and job performance (Chenhall \& Brownell, 1988; Kren, 1992; and Parker \& Kyj, 2006).

\subsection{Budget adequacy}

Parker and Nouri (1998) define budget adequacy as the degree to which manager perceives enough and adequate budgeted resources to fulfil their job requirements. Several accounting studies research the impact of budget participation on budget adequacy (see Merchant, 1981; Parker \& Nouri, 1998), as they assume that managers will attempt to participate in the budget process to have adequate resources for their departments. This study proposes that manager related factors such as position, qualification or may be the experience may enable managers to get adequate budgeted resources to their department. In this manner, manager and department related factors many have such a relation to budget adequacy as one of budget participation characteristics.

Various researchers have stated that subordinates participation in budgeting process may well result in the disclosure of private information that could result in more accurate budget (Merchant, 1981; Nouri \& Parker, 1998). As Young (1985) explains that budget adequacy differs with slack budget that budget adequacy does not necessarily involve excess resources or biased budget forecasts as occurs in budget slack. Nouri \& Parker (1998) propose that employees with adequate budgetary would support on average exhibit higher performance than employees without adequate budgetary support. They find that budget participation have an effect on job performance indirectly via budget adequacy.

\subsection{Budget feedback}

It is one of the important motivational variables measuring the degree to which budget goals have been achieved (Kenis, 1979). While many researchers have examined the relation between the budget feedback and the performance (see Kenis, 1979; Nouri \& Kyj, 2008; and Gladney et al., 2009), none, to the knowledge of the researchers, have directly examined the relationship between the manager and department related factors with budget feedback. Kenis (1979) finds that budget feedback related positively to the job satisfaction, and budgetary motivation. Gladney et al. (2009) conclude that budget meeting with budget committee members enhances the budgetary communication between the managers and the supervisor in term of budgetary feedback. The current 
study proposes and tests a direct relation between the manager and department related factor and the budget feedback.

Budgetary Feedback is the feedback about the degree to which department's managers have achieved their budget goals (Kenis, 1979) and the degree to which superiors (top management) provide feedback to department's heads about their achievement of budget goals. The logic behind using budget feedback as variable was explained by (Kenis, 1979) that if department's budget functionary do not know the results of his effort, he will lost any feeling of success or failure and incentive for better performance. Flamholtz et al. (1985) has studied the feedback as a control mechanism, explained that the information which is needed in order to correct individual behaviour, is given to individual by the feedback.

Budget feedback could be either direct "face to face meetings" or indirect through reports or written explanations. Further, face to face meetings provide opportunities for supervisors to explain directly the reasons for their budget decisions to the subordinate manager and to provide feedback for the manager's achievement of budget goals (Gladney et al., 2009). Flamholtz et al. (1985) state that feedback information could be either specific to the work goals or general, or about work behaviour or work outcomes. Thus, the feedback process information may depend on the nature of the work goals or on the measurement system (Flamholtz et al., 1985).

\section{Research method and research sample}

In this section, study method for collecting the data and the study sample is presented.

\subsection{The study variables and the hypothesis}

This research identified manager's position, qualification, major, general experience, experience earned in the university, budget experience, department type, department size as a contextual variables. The following is a discussion regarding to these factors.

\subsubsection{Contextual variables;}

The respondent position: Respondent's position varies as the study surveyed deans, academic department head, and administration department head.

The qualification: In such a sample like the universities, big variation appears in the qualification between the respondents, where there are some respondents holding degrees of $\mathrm{PhD}$, master, $\mathrm{BSc}$, and others do not have.

The major: This is to verify if the manager majors could influence the achievement of budget. Majors vary between business, engineering, IT and others.

General experience: General experience could be one of the factors that affect positively dealing with budget.

Experience in the university: To examine whether the experience which has been earned in the university affects the budget characteristics.

Budget experience: The budget experience indicates that the respondent is familiar with using the budget where this may affect positively the budget performance.

The department size: This factor has been measured using two main tools

(1) Employees' number: It is clear that number of employees indicates the size of the department, while its influence is not obvious.

(2) Total of the expenses: Expenses may indicate the size of the department; its impact has been studied in the current research.

Department Type: University departments could be academic or administrative. An academic department, which contributes directly to the education, is leaded by an academic member. Administrative department, which serve the education process, could be leaded by academic or non-academic staff.

\subsubsection{Hypotheses}

Prior studies have clarified that contextual and environmental variables have an impact in budget characteristics. This research comes to extend the literature and to investigate potential impact of the managers and department features on budget characteristics using a unique environment and country. The independent variables which have been researched are (manager position, qualification, major, general experience, organisational experience, budget experience department size and department type). This leads to use eight propositions in order to assess the above relationships. One of the main reasons behind using these assumptions is that after considering the environment in Jordan, it is obvious that private universities need to develop its strategies and to avoid consuming undesirable expenses, which may occur when there is a development in the budget system.

H 1: The position of the respondent has a significant positive association with budget participation, information sharing, goal clarity, budget adequacy, and budget feedback. 
$\mathrm{H}$ 2: There is a significant positive relation between the qualification and budget participation, information sharing, goal clarity, budget adequacy, and budget feedback

H 3: There is a significant positive association between the major of the subordinate manager and with budget participation, information sharing, goal clarity, budget adequacy, and budget feedback.

H 4: General experience has a significant positive association with budget participation, information sharing, goal clarity, budget adequacy, and budget feedback.

H 5: There is a significant positive relationship between the experience earned in the university and with budget participation, information sharing, goal clarity, budget adequacy, and budget feedback

H 6: Budget experience affects positively the budget participation, information sharing, goal clarity, budget adequacy, and budget feedback.

H 7: There is a significant positive association between the size of the department and budget participation, information sharing, goal clarity, budget adequacy, and budget feedback.

$\mathrm{H}$ 8: There is a significant positive association between the type of the department activities and budget participation, information sharing, goal clarity, budget adequacy, and budget feedback.

\subsection{Data collection method}

The influence of manager and department related factors as independent variables on budget related factors as dependent variables in JPUs has been measured using questionnaire and documentary data. In summer of 2010, a survey questionnaire was distributed to a sample of 131 department managers in five private universities. Those managers were identified as having responsibility for their department expenses in the private Jordanian universities. Respondents were chosen from a variety of functional areas, including academics and administrative members. The president of Applied Science University assisted the researcher by writing a formal cover letter to MoHE and all Jordanian universities to lend a hand in this survey. Initially, these letters were given to the president of each of the selected universities. These letters explained the purpose of the study, asked the presidents to nominate department managers to take part in the study and solicited their permission to contact the nominated department managers. A copy of the questionnaire was attached to the presidents' letter for their information. Seven universities were researched, while five agreed to help with this survey.

\subsubsection{Questionnaire structure}

In addition to the covering letters, this survey addressed three main parts to shed light in the general information regarding to the respondents' characteristics and other factors intended to be studied. Moreover, this division employed to assist the use of statistical analysis. First and second parts are close ended while the third one is open ended. These parts are explained as the following:

\section{Part one:}

Questions regarding to the respondents characteristics (such as position, qualification, major, general experience, budget experience, experience earned in the university, age, gender, and nationality) were included. Questions about the department were conducted (such as, employees number, the total of department expenses and the type of the department (Academic or Administrative). However, this part aimed to provide general information about the respondents; it is obvious that this part will verify the independent factors that influence the individual use of the budget.

\section{Part two:}

This part consists of 25 instruments distributed to five groups of questions using seven point Likert scale. These instruments are for budget participation, information sharing six instruments, budget goal clarity six instruments, budget adequacy three instruments and budget feedback three instruments. This part aimed to survey the perception of the respondents about the above factors.

\subsubsection{Measurement of the budget characteristics}

A survey questionnaire has been implemented in this paper. The response format was a seven point Likert-type for all the questions and variables. Heads of department were asked about their characteristics and their department characteristics. Moreover, the budgetary participation variables measured in the questionnaire Included, budget participation, information sharing, budget adequacy, clarity of the rules, and budget feedback.

Budget participation was measured using modified version of Milani's (1975) seven-item scale was used. This format has been used extensively in the previous literature (Shields \& Shields, 1998; Nouri \& parker, 1998; and Parker \& Kyj, 2006). The instruments attempted to determine involvement in and influence of the individuals on the budget process (Nouri \& parker, 1998). The response scale was a seven point Likert-type scale ranging from one 
(very unsatisfied) to seven (very satisfied). A reliability check of the instruments for the current study has produced a Cronbach alpha coefficient of 0.934 .

Information sharing was measured using six-item scale, two of them employed by (Parker \& Kyj, 2006) and four instruments have been developed for this study. The response scale was a seven-point Likert type scale ranging from one (very little) to seven (very much). As for the reliability, the Cronbach alpha coefficient was 0.899 .

Budget goal clarity was measured in this study by adopting a modified version of six-item scale developed by Rizzo et al. (1970). These instruments have been largely employed in the literature see (Shields \& Shields, 1998; Nouri \& Kyj, 2008). Participants were asked to respond to each item in the instrument on a seven-point Likert scale ranging from one (strongly disagree) to seven ( strongly agree). To measure the reliability, Cronbach alpha was 0.915 .

Budget adequacy was measured using a three-item scale developed by (Nouri \& Parker, 1998). The instruments attempted to explore the respondents' perception about their budgeted resources as far as the adequacy of the performance of job responsibilities. The response scale was a seven-point Likert-type scale ranging from one (strongly disagree) to seven (strongly agree). As for the reliability of the scale, the Cronbach alpha coefficient was 0.944. Three-item scale used to measure budgetary feedback. These items were involved to measure the degree to which budgetary goals have been achieved. Kenis, (1979) believes that the individual will have no basis for feelings of success or failure and no incentives for higher performance, if he does not know what are their effort results. In this study, the Cronbach alpha was 0.945 .

\subsubsection{The sample}

Several procedures were considered in selecting the study sample. Pollanen's (1996) criteria to select a sample in a specific segment have been considered along with general criteria established for sample selection. Rational for every procedure is clarified. However, the sample was chosen to cover all private Jordanian universities, some universities that have relatively small students number, few majors or difficult to be accessed, were excluded. (Zikmund, 2000) commented, "It is a serious mistake to rush into detailed surveys before less expensive and more readily available sources of information have been exhausted." Tashakkori \& Teddlie (2009) supported this approach.

Universities in Jordan are two types regarding governance and financing: public universities supervised and financed by governments, and private universities supervised and financed by non-governmental institutions. Notwithstanding, private universities operate as autonomous institutions, managing income resources, choosing strategic plans, managerial systems and following government laws (Companies laws, Education laws, and Tax laws). Jordanian universities sector particularly the private universities sector was the study application entity. To distribute the questionnaire, two primary criteria were followed in selecting universities in this specific segment. First, Like Pollanen criterion, this survey distributed to universities which are large enough to have a well developed organisational structure with multiple levels of management to allow the selection of middle management with budgeting responsibilities. The researchers did not distribute the questionnaires in some universities because it found that these universities are new or does not have diversity in the majors. Second, to investigate the individual variables -as the aim of this paper- variations among managers' characteristics or departments had to exist. This point was considered very important that the different between those managers in terms of their characteristics which may affect the usage of budget.

The survey in this study (the questionnaire survey) yielded 131 cost centre managers who hold management responsibilities of his department in private Jordanian universities. The responses were obtained from five private universities. From a 131 surveys were distributed, 79 were returned, of which two had irrelevant data. The effective response rate is $58.8 \%$ (77/131). The main advantage of researching this number of universities is to enable the researchers to gain an intimate understanding of organisational phenomena, and to generalise results to private Jordanian universities.

\section{Results and analysis}

This section includes analysis of the survey questionnaire and results presentation; begins with clarifying the features of the respondents and then using descriptive statistics for analysing the variables. The analysis ends by presenting the results using a kendall's tau-b to test the study hypotheses, table 3 display these results. Limitations of this study have been presented after that.

\subsection{Sample descriptive analysis}

The results pointed out that the sample respondents had been employed by their universities for an average of above 8 years, and had held the responsibility of budget for an average of 5.6 years. The average of the respondents' age is 47 with general experience of a mean of 20 years. More than third of the respondents have business qualification, which may indicate some budget knowledge. The mean of the employees' number in these departments is more than the 19 employees, where an average of the total annual expenses of about JD 80000 approx $(\$ 113000)$. These 
demographic data suggests that the respondents have good experience and holding responsible positions. In addition to the previous characteristics, the following demographic data were also collected: manager position, educational level, gender, and nationality. Moreover, the department type and size have been addressed (see table 1).

The impact of managers and department related factors on budget participation characteristics has been tested by means of calculation a non parametric test. Kendall's Tau-b correlation coefficient is one of the bivariate tests that has used widely in the literature and suited to the questionnaire data (see Ezzamel, 1990). Table 2 displays the results, presenting the relationship between independent and dependent variables. The results show that there is no such relation between the manager's positions either dean, administrative manager or academic manager and the budget participation, information sharing, goal clarity, budget adequacy and budget feedback. Thereby, these results indicate that there $\mathrm{H} 1$ cannot be accepted as there is no significant relationship between the budget characteristics and the position of the department manager. The results therefore suggest that manager position as it could be in this study dean, academic department head or administrative department head has no significant impact on budget participation characteristics.

Regarding to the second hypothesis, the results were unexpected, as hypothesized that there is a relationship between the qualification and budget participation characteristics. According to the results, it is clear that there is no such significant relation between the qualification degree and the degree of participation, information sharing, goal clarity, budget adequacy and budget feedback. Thereby, this result shows that the qualification degree hold by the manager of the department has no significant effect on characteristics of the budget participation.

Similarly, the results relating to the major or the specialisation of the manager are also claiming that there is no significant evidence that the manager major has any relationship to any of the budget characteristics defined in this study. This result similar to the results of the position and qualification appear in table 2 . Therefore, the results conducted failed to address any relationship between the major of the manager either business, IT, engineering or any other major and the budget participation characteristics. This result contrast to the hypothesis which assumes that the manager field has relationship to the budget characteristics (as there is a difference between the managers who have a business major and other majors)

The results appear in table 2 regarding to the general experience is disappointing and unexpected. It was expected that the experience appears to have an influence on the budget participation characteristics, the result appear in table 2 explains that the general experience have no significant relation to the budget characteristics. According to the universities age this may lead to the fact that, it is not necessary that those who have long general experience have earned it in their university. Moreover, the oldest private university at the time of the empirical work had seventeen years old as this may support this fact.

Experience earned in the university expected to have an influence because managers who have been in this organisation for long period should be more involved in participating in the budget. This has been noticed during the time of collecting the questionnaire where some financial managers emphasis this point. As appeared in table 2, the results indicate that experience earned in the university is positively associated with budget participation at significant level of 0.01 , Information sharing at level of 0.05 , goal clarity at 0.05 , budget adequacy 0.01 , and budget feedback at 0.01 . These results indicate that the manager experience which earned in the university have an effect on the budget characteristics.

One of the most confused results is the results appeared regarding to the budget experience. This factor explained as the time of experience being a budget holder or responsible on your department budget. It was expected to find a strong relation between this factor and the budget characteristics. Table 2 indicates that there is a week relation support the $\mathrm{H} 6$ as budget participation and budget adequacy variables show significant relation to the budget experience, but other variables of information sharing, budget adequacy and budget feedback have no significant relationship. The results therefore suggest that the budget experience as defined in the study has limited impact on budget characteristics.

Similar to the first, second, third and the forth variables the table shows that the seventh, eighth and ninth variables have no significant relationship to the budget characteristics variables. Therefore, the department characteristics either the size or the type does not appear to have any considerable influence on budget participation characteristics. The size has been measured by the employees' number in each department and the annual total expenses in these departments. The results did not support the hypothesis that department size have an association to the budget characteristics. Moreover, the results indicate that the nature of these departments either academic or administrative has no significant influence on the budget participation characteristics.

\section{Discussion}

The relationship between manager and department related variables in one side and so called budget characteristics have been investigated in this paper. The findings of this study can be summarized in the following three points: 
First manager related factors of position, qualification, major and general experience are not correlated with budget characteristics in this study.

Second, organisational experience positively related to all budget characteristics, but budget experience correlated significantly with budget participation and budget adequacy and does not appear to have significant relation with information sharing, goal clarity and budget feedback.

Third, department factors are not significantly related with any of the budget characteristics.

Thereby, the data suggest that the department factors and the manager factors except the experience earned in the university and the budget experience have no impact on budget characteristics. Hence, the budget characteristics may be influenced by other factors such as the management style, departmental autonomy, and other factors (see Ezzamel, 1990).

The results can develop several complementary lines of argument; first of all, the study is an attempt to draw attention behind the budget usage in private universities. Thereby, studying the impact of different factors such as the managerial uncertainty, the university size, or budget slack and performance evaluation on budget characteristics particularly budget participation characteristics appears to be one of interesting topics for further research in this area. A further issue lies in the sampling choice as restricting the sample to a single sample or to conduct rang of organisations as a study sample. This issue arose that studying one university enable the researchers to control the effect of the differences in organisational controls. However, this may increase the understanding of the manner in which variables interact in specific setting, this study focus more on providing more generalisation. A third point lies that the impact of budget characteristics on managerial performance. This is one of the central topics appears in the literature related to budget participation and budget characteristics impact (see Otley, 1978; Hopwood, 1974; Chenhall \& Brownll 1988; Dunk, 1993; Nouri \& parker, 1998; and Shields \& Shields, 1998). Another line may lie is the research methods implemented in this study. Most of the prior studies who conducted the selected budget characteristics focus upon questionnaire based methods of measurements (see Nouri \& Parker, 1998; Shields \& Shields, 1998; Otley \& Pollanen, 2000; Parker \& Kyj, 2006; and Milani, 1975). The main aim of this research is the development of understanding about the usage of budget issues in different sites; thus the questionnaire considers one of the best ways of gathering the perception and views of that number of department managers.

This study may be considered to have the usual limitations of the questionnaire survey methodology. Using the managers' perceptions, which may be subject to recall bias or any other interpretation of the internal relation, to measure the dependent variables have been criticized on the basics that these perceptions are not objective. This might not consider a serious limitation since managers' take decisions and actions relying on their perceptions and views. However, questionnaire considers one of the most useful ways for collecting data on specific topic or populations, it could be criticized because it does not allow in depth understanding of complex phenomenon (Moll, 2003). Moreover, the study sample can be criticised that private universities in Jordan are 17 universities and the study has conducted five universities. In fact, the time and the access were a challenge for the researchers to undertake all the private universities. Furthermore, the researchers studied one or two universities of each stage of the universities stages which have been clarified in the sample section.

Despite the insights this research may provide, the results have been difficult to integrate, and have been conflicting specially with regards to the general experience and budget experience. Another limitation which could be considered is the impact of other variables such as decentralization, managerial autonomy, environmental uncertainty and university overall characteristics on the study sample whereas these factors may influence the budget process in theses universities and the level of participation. However, studying budget characteristics in private universities might be influenced by those factors, this study focused on studying the impact of manager's related factors and department related factors on budgetary characteristics. This could be a considerable limitation in areas that have been extensively researched but the budget characteristics in private Jordanian universities have not been extensively researched in the literature. The researchers think that different streams should be researched in future studies such relations between above variables and budget participation characteristics as well as the budget characteristics and performance. These future studies should provide more evidence regarding the role of budget participation and its impact on managerial performance.

\section{References}

Broadbent, J. (2007). If You Can't Measure It, How Can You Manage It? Management and Governance in Higher Educational Institutions. Public Money and Management 27(3): 193-198. doi:10.1111/j.1467-9302.2007.00579.x, http://dx.doi.org/10.1111/j.1467-9302.2007.00579.x

Brownell, P. and M. Hirst (1986). Reliance on Accounting Information, Budgetary Participation, and Task Uncertainty: Tests of a Three-Way Interaction. Journal of Accounting Research 24(2): 241-249. doi:10.2307/2491132, http://dx.doi.org/10.2307/2491132 
Brownell, P. and M. McInnes (1986). Budgetary Participation, Motivation, and Managerial Performance. The Accounting Review 61(4): 587-612.

Bruns, W. J. and J. H. Waterhouse (1975). Budgetary Control and Organisation Structure. Journal of Accounting Research 13(2): 177-203. doi:10.2307/2490360, http://dx.doi.org/10.2307/2490360

Charpentier, C. (1998). Budgetary Participation in a Public Service Organisation, Working Paper Series in Business Administration. 2009.

Chenhall, R. H. and P. Brownell (1988). The Effect of Participative Budgeting on Job Satisfaction and Performance: Role Ambiguity as an Intervening Variable. Accounting, Organisations and Society 13(3): 225-233. doi:10.1016/0361-3682(88)90001-3, http://dx.doi.org/10.1016/0361-3682(88)90001-3

Chong, V. K. and K. M. Chong (2002). Budget Goal Commitment and Informational Effects of Budget Participation on Performance: A Structural Equation Modelling Approach. Behavioural Research in Accounting 14: 65-86. doi:10.2308/bria.2002.14.1.65, http://dx.doi.org/10.2308/bria.2002.14.1.65

Covaleski, M., I. Evans, H. John, J. Luft and M. D. Shields (2003). Budgeting Research: Three Theoretical Perspectives and Criteria for Selective Integration. Journal of Management Accounting Research 15: 3-49. doi:10.2308/jmar.2003.15.1.3, http://dx.doi.org/10.2308/jmar.2003.15.1.3

Drury, C. (2008). Management and Cost Accounting. London, Thomson Learning, Business Press.

Dunk, A. S. (1993). The Effect of Budget Emphasis and Information Asymmetry on the Relation between Budgetary Participation and Slack. The Accounting Review 68(2): 400-411.

Ezzamel, M. (1990). The Impact of Environmental Uncertainty, Managerial Autonomy and Size on Budget Characteristics. Management Accounting Research 1(3): 181-197. doi:10.1016/S1044-5005(90)70057-1, http://dx.doi.org/10.1016/S1044-5005(90)70057-1

Flamholtz, E. G., T. K. Das and A. S. Tsui (1985). Toward an Integrative Framework of Organisational Control. Accounting, Organisations and Society 10(1): 35-50. doi:10.1016/0361-3682(85)90030-3, http://dx.doi.org/10.1016/0361-3682(85)90030-3

Gladney, L., R. Welker and N. Magner (2009). An Experimental Study of the Effects of Budget Favourability on the Formation of Pseudo-Participation Perceptions. Advances in Management Accounting 17: 217-245.

Hofstede, G. (1981). Management Control of Public and Not-for-Profit Activities. Accounting, Organisations and Society 6(3): 193-211. doi:10.1016/0361-3682(81)90026-X, http://dx.doi.org/10.1016/0361-3682(81)90026-X

Hopwood, A. G. (1974). Leadership Climate and the Use of Accounting Data In Performance Evaluation. The Accounting Review 49(3): 485-493.

Kenis, I. (1979). Effects of Budgetary Goal Characteristics on Managerial Attitudes and Performance. The Accounting Review 54(4): 707-721.

Kren, L. (1992). Budgetary Participation and Managerial Performance: The Impact of Information and Environmental Volatility. The Accounting Review 67(3): 511-526.

Lau, C. M. and E. W. Lim (2002). The Effects of Procedural Justice and Evaluative Styles on the Relationship between Budgetary Participation and Performance. Advances in Accounting 19: 139-160. doi:10.1016/S0882-6110(02)19008-0, http://dx.doi.org/10.1016/S0882-6110(02)19008-0

Lillis, D. (2006). The Systematic Evaluation of a Strategic Management Program in an Irish Institute of Technology. Tertiary Education and Management 12(3): 241-256. doi:10.1080/13583883.2006.9967171, http://dx.doi.org/10.1080/13583883.2006.9967171

Lukka, K. (1988). Budgetary Biasing in Organisations: Theoretical Framework and Empirical Evidence. Accounting, Organisations and Society 13(3): 281-301. doi:10.1016/0361-3682(88)90005-0, http://dx.doi.org/10.1016/0361-3682(88)90005-0

Mah'd, O., (2010). The budgetary process in Private Jordanian Universities (PJUs) and the role of budget participation. Unpublished PhD Thesis, School of Accounting and Finance. Aberdeen, University of Aberdeen.

Mah'd, O., and Buckland, R. (2009) The budget process in Jordanian Private Universities (JPUs) Accounting in Emerging Economies (9): 193-228.

Mahoney, T., T. Jerdee and S. Carroll (1965). The Jobs of Management. Industrial Relations 4: 97-110. doi:10.1111/j.1468-232X.1965.tb00922.x, http://dx.doi.org/10.1111/j.1468-232X.1965.tb00922.x

Marshall, C. and G. B. Rossman (1999). Designing Qualitative Research, Thousand Oaks: Sage Publications.

Merchant, K. A. (1981). The Design of the Corporate Budgeting System: Influences on Managerial Behaviour and Performance. The Accounting Review 56(4): 813-829.

Mia, L. (1989). The Impact of Participation in Budgeting and Job Difficulty on Managerial Performance and Work Motivation: A Research Note. Accounting, Organisations and Society 14(4): 347-357. doi:10.1016/0361-3682(89)90005-6, http://dx.doi.org/10.1016/0361-3682(89)90005-6

Mia, L. and A. Patiar (2002). The Interactive Effect of Superior-Subordinate Relationship and Budget Participation on Managerial Performance in the Hotel Industry: An Exploratory Study. Journal of Hospitality \& Tourism Research 26: 235-257. doi:10.1177/1096348002026003003, http://dx.doi.org/10.1177/1096348002026003003 
Milani, K. (1975). The Relationship of Participation in Budget-Setting to Industrial Supervisor Performance and Attitudes - A Field Study. The Accounting Review 50(2): 274-288.

Moll, J. (2003). Organisational Change and Accounting Control Systems at an Australian University; A Longitudinal Case Study. Unpublished PhD Thesis, School of Accounting and Finance. Griffith, Griffith University. Neuman, W. L. (2000). Social Research Methods: Qualitative and Quantitative Methods. Boston, MA: Allyn and Bacon.

Nouri, H. and L. Kyj (2008). The Effect of Performance Feedback on Prior Budgetary Participative Research Using Survey Methodology: An Empirical Study. Critical Perspectives on Accounting 19(8): 1431-1453. doi:10.1016/j.cpa.2007.11.003, http://dx.doi.org/10.1016/j.cpa.2007.11.003

Nouri, H. and R. Parker (1998). The Relationship between Budget Participation and Job Performance: The Roles of Budget Adequacy and Organisational Commitment. Accounting, Organisations and Society 23(5-6): 467-483. doi:10.1016/S0361-3682(97)00036-6, http://dx.doi.org/10.1016/S0361-3682(97)00036-6

O'Dwyer, B. G. (1999). Corporate Social Reporting: A Description and Quest for Understanding. Unpublished PhD Thesis, Dundee, Dundee University.

Otley, D. (1978). Budget Use and Managerial Performance. Journal of Accounting Research 16(1): 122-149. doi:10.2307/2490414, http://dx.doi.org/10.2307/2490414

Otley, D. and Pollanen (2000). Budgetary criteria in performance evaluation: a critical appraisal using new evidence. Accounting, Organisational and Society 25: 483-496. doi:10.1016/S0361-3682(98)00031-2, http://dx.doi.org/10.1016/S0361-3682(98)00031-2

Parker, R. J. and L. Kyj (2006). Vertical Information Sharing in the Budgeting Process. Accounting, Organisations and Society 31(1): 27-45. doi:10.1016/j.aos.2004.07.005, http://dx.doi.org/10.1016/j.aos.2004.07.005

Patton, M. Q. (1989). Qualitative evaluation methods. Beverly Hills, CA: Sage.

Pollanen, R. M. (1996). Budgetary Criteria in Performance Evaluation and Organisational Effectiveness in the Public Sector; an Empirical Investigation in Ontario Colleges and Universities. Unpublished PhD, Thesis, Lancaster, Lancaster University.

Rizzo, J., R. House and S. Lirtzman. (1970). Role Conflict and Ambiguity in Complex Organisations. Administrative Science Quarterly 15(3): 150-163. doi:10.2307/2391486, http://dx.doi.org/10.2307/2391486

Saunders, M., P. Lewis and A. Thornhill (2000). Research Methods for Business Students. London, Prentice Hall.

Sekaran, U. (2000). Research Methods for Business. New York, Hermitage Publishing Services.

Shields, J. F. and M. D. Shields (1998). Antecedents of Participative Budgeting. Accounting, Organisations and Society 23(1): 49-76. doi:10.1016/S0361-3682(97)00014-7, http://dx.doi.org/10.1016/S0361-3682(97)00014-7

Shields, M. D. and S. M. Young (1993). Antecedents and Consequences of Participative Budgeting: Evidence on the Effects of Asymmetrical Information. Journal of Management Accounting Research 5: 265-288.

Stedry, A. C. (1960). Budget Control and Cost Behaviour. New Jersey, Englewood Cliffs, Prentice-Hall.

Thys-Clement, F. and L. Wilkin (1998). Strategic Management and Universities: Outcomes of a European Survey. Higher Education Management 10(1): 13-28.

Weetman, P. (2006). Financial and Management Accounting: an Introduction. Edinburgh, FT Prentice Hall.

Yin, R. K. (2003). Case Study Research: Design and Methods. London, Sage Publishing.

Young, S. M. (1985). Participative Budgeting: The Effects of Risk Aversion and Asymmetric Information on Budgetary Slack. Journal of Accounting Research 23(2): 829-842. doi:10.2307/2490840, http://dx.doi.org/10.2307/2490840

Zikmund, W. G. (2000). Business research methods. Orlando, USA, Dryden Press. 
Table 1. Sample descriptive analysis

\begin{tabular}{|c|c|c|c|c|c|c|}
\hline Position & $\begin{array}{l}\text { Head Of Admin } \\
\text { Dep }\end{array}$ & Dean & $\begin{array}{l}\text { Head of } \\
\text { Academic Dep }\end{array}$ & Others & & Total \\
\hline $\begin{array}{l}\text { Frequencies } \\
\text { and } \%\end{array}$ & $\begin{array}{l}35 \\
45.5 \\
\end{array}$ & $\begin{array}{l}14 \\
18.2\end{array}$ & $\begin{array}{l}25 \\
32.5 \\
\end{array}$ & $\begin{array}{l}3 \\
3.9\end{array}$ & & 77 \\
\hline Qualification & Under BSc & $\mathrm{BSc}$ & Master & $\mathrm{PhD}$ or above & & Total \\
\hline $\begin{array}{l}\text { Frequencies } \\
\text { and } \%\end{array}$ & $\begin{array}{l}4 \\
5.2\end{array}$ & $\begin{array}{l}20 \\
26\end{array}$ & $\begin{array}{l}9 \\
11.7\end{array}$ & $\begin{array}{l}44 \\
57.1\end{array}$ & & 77 \\
\hline Major & Accounting & Management & Engineering & IT & Other & Total \\
\hline $\begin{array}{l}\text { Frequencies } \\
\text { and } \%\end{array}$ & $\begin{array}{l}9 \\
11.7 \\
\end{array}$ & $\begin{array}{l}13 \\
16.9\end{array}$ & $\begin{array}{l}8 \\
10.4 \\
\end{array}$ & $\begin{array}{l}9 \\
11.7\end{array}$ & $\begin{array}{l}38 \\
49.4\end{array}$ & 77 \\
\hline General experience & Under 5 Years & $5-14$ & $15-24$ & 25 or above & & Total \\
\hline $\begin{array}{l}\text { Frequencies } \\
\text { and } \%\end{array}$ & $\begin{array}{l}4 \\
5.2 \\
\end{array}$ & $\begin{array}{l}24 \\
31.2 \\
\end{array}$ & $\begin{array}{l}29 \\
37.7 \\
\end{array}$ & $\begin{array}{l}20 \\
26 \\
\end{array}$ & & 77 \\
\hline Organisational experience & Under 5 & $5-9$ & 10 or above & & & Total \\
\hline $\begin{array}{l}\text { Frequencies } \\
\text { and } \%\end{array}$ & $\begin{array}{l}26 \\
33.8 \\
\end{array}$ & $\begin{array}{l}22 \\
28.6 \\
\end{array}$ & $\begin{array}{l}29 \\
37.7 \\
\end{array}$ & & & 77 \\
\hline Budget experience & Under 3 & 3-9 Years & 10 or above & & & Total \\
\hline $\begin{array}{l}\text { Frequencies } \\
\text { and } \%\end{array}$ & $\begin{array}{l}32 \\
41.6 \\
\end{array}$ & $\begin{array}{l}34 \\
44.2 \\
\end{array}$ & $\begin{array}{l}11 \\
14.3 \\
\end{array}$ & & & \\
\hline Age & Under 30 & $30-59$ & 60 or Above & & & Total \\
\hline $\begin{array}{l}\text { Frequencies } \\
\text { and } \%\end{array}$ & $\begin{array}{l}5 \\
6.5 \\
\end{array}$ & $\begin{array}{l}58 \\
75.3 \\
\end{array}$ & $\begin{array}{l}14 \\
18.2 \\
\end{array}$ & & & \\
\hline Gender & Male & Female & & & & Total \\
\hline $\begin{array}{l}\text { Frequencies } \\
\text { and } \%\end{array}$ & $\begin{array}{l}71 \\
92.2\end{array}$ & $\begin{array}{l}6 \\
7.8 \\
\end{array}$ & & & & 77 \\
\hline Nationality & Jordanians & Syrian & Iraqis & Egyptian & Other & Total \\
\hline $\begin{array}{l}\text { Frequencies } \\
\text { and } \%\end{array}$ & $\begin{array}{l}72 \\
93.5 \\
\end{array}$ & $\begin{array}{l}1 \\
1.3 \\
\end{array}$ & $\begin{array}{l}3 \\
3.9 \\
\end{array}$ & $\begin{array}{l}1 \\
1.3 \\
\end{array}$ & $\begin{array}{l}0 \\
0 \\
\end{array}$ & 77 \\
\hline $\begin{array}{l}\text { Number of the employees in the } \\
\text { Department }\end{array}$ & Under 10 & $10-19$ & $20-29$ & 30 or above & & Total \\
\hline $\begin{array}{l}\text { Frequencies } \\
\text { and } \%\end{array}$ & $\begin{array}{l}33 \\
42.9 \\
\end{array}$ & $\begin{array}{l}29 \\
37.7 \\
\end{array}$ & $\begin{array}{l}5 \\
6.5 \\
\end{array}$ & $\begin{array}{l}10 \\
13\end{array}$ & & 77 \\
\hline Department Expenditures & Under $30000 \mathrm{JD}$ & $30000-50000$ & $150000-400000$ & $\begin{array}{ll}400000 & \text { or } \\
\text { above }\end{array}$ & $\begin{array}{l}\text { Don't } \\
\text { know }\end{array}$ & Total \\
\hline $\begin{array}{l}\text { Frequencies } \\
\text { and } \%\end{array}$ & $\begin{array}{l}31 \\
40.3 \\
\end{array}$ & $\begin{array}{l}25 \\
32.5 \\
\end{array}$ & $\begin{array}{l}7 \\
9.1 \\
\end{array}$ & $\begin{array}{l}4 \\
5.2 \\
\end{array}$ & $\begin{array}{l}10 \\
13 \\
\end{array}$ & 77 \\
\hline Dep Type & Academic & Administrative & & & & Total \\
\hline $\begin{array}{l}\text { Frequencies } \\
\text { and } \%\end{array}$ & $\begin{array}{l}41 \\
53.2\end{array}$ & $\begin{array}{ll}36 \\
46.8 \\
\end{array}$ & & & & 77 \\
\hline
\end{tabular}

Table 2. Kendall's tau-b correlations for independent and dependent variables $(\mathrm{n}=77)$

\begin{tabular}{|c|c|c|c|c|c|c|c|c|c|}
\hline $\begin{array}{c}\text { Dependent } \\
\text { Variables }\end{array}$ & 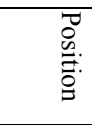 & 䒿. & : & 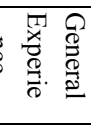 & 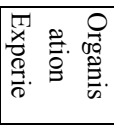 & 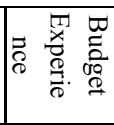 & $z \& \frac{\pi}{\stackrel{5}{0}}$ & 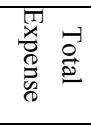 & 究 \\
\hline Budget Participation & -0.065 & 0.038 & -0.029 & 0.015 & $* * 0.279$ & *0.192 & 0.012 & -0.095 & -0.109 \\
\hline Information Sharing & 0.019 & 0.028 & 0.035 & -0.017 & $\star 0.220$ & 0.072 & -0.045 & -0.044 & -0.056 \\
\hline Goal Clarity & -0.095 & 0.000 & 0.118 & 0.152 & $* 0.202$ & 0.108 & 0.018 & 0.023 & -0.022 \\
\hline Budget Adequacy & -0.057 & -0.009 & 0.007 & 0.151 & $\star * 0.348$ & $\star * 0.262$ & 0.084 & -0.117 & -0.030 \\
\hline Budget feedback & -0.040 & 0.124 & 0.087 & 0.007 & $\star * 0.273$ & 0.094 & -0.039 & -0.049 & -0.076 \\
\hline
\end{tabular}

* Correlation is significant at the 0.05 level ** Correlation is significant at the 0.01 level 
Table 3. University Stage, Establishment, Student number in 06,07 and 08 and the location

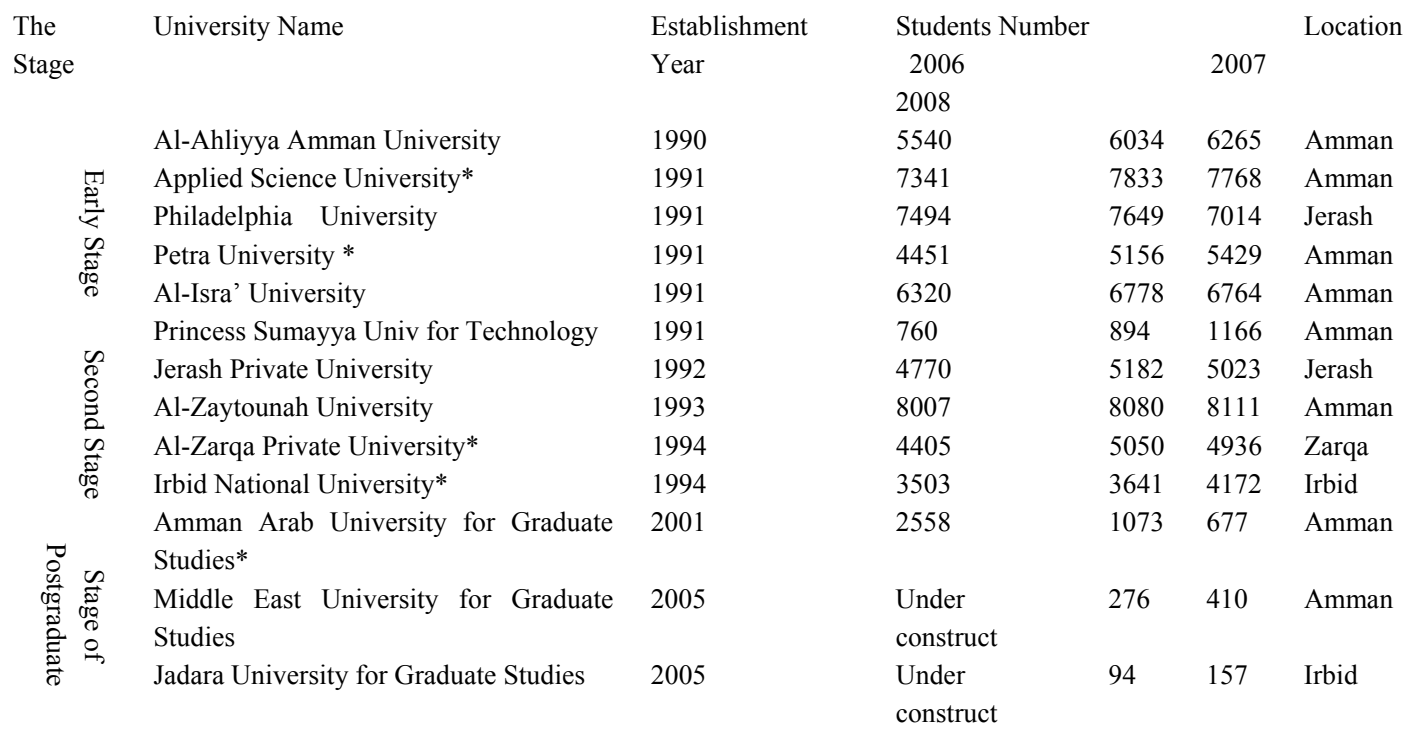

* The study sample

Table 4. This table explains the respondents' demographic data Where, DH is Department Head, AH is

\begin{tabular}{|l|l|l|l|l|l|l|}
\hline The university & Sent & DH & Dean & AH & Male/Female & Academic/ Administrative \\
\hline ASU & 55 & 14 & 6 & 16 & $34 / 2$ & $15 / 21$ \\
\hline ZPU & 33 & 10 & 4 & 5 & $17 / 2$ & $10 / 9$ \\
\hline AAU & 15 & 7 & 1 & 0 & $6 / 2$ & $1 / 7$ \\
\hline INU & 17 & 5 & 2 & 1 & $8 / 0$ & $3 / 5$ \\
\hline Petra & 11 & 0 & 1 & 5 & $6 / 0$ & $6 / 0$ \\
\hline Jordan University (JU) & 4 & 0 & 0 & 0 & 0 & 0 \\
\hline Al-Isra'a Private University (IPU) & 6 & 0 & 0 & 0 & 0 & 0 \\
\hline University of Al-Yarmouk (YU) & 1 & 0 & 0 & 0 & 0 & 0 \\
\hline Jarash University & 2 & 0 & 0 & 0 & 0 & 0 \\
\hline Total & 144 & 36 & 14 & 27 & 77 & 77 \\
\hline
\end{tabular}

Academic Head 